\title{
Estimation of serum 25 hydroxy vitamin D level and its correlation with metabolic and endocrine dysregulation in women with PCOS
}

\author{
Vandana Solanki ${ }^{1 *}$, Amrita Chaurasia ${ }^{2}$, Shalini Singh², Shikha Sachan ${ }^{3}$, \\ Kachanar Varma ${ }^{2}$, Rekha Devi ${ }^{2}$
}

\begin{abstract}
${ }^{1}$ Department of Obstetrics and Gynecology, King George's Medical University, Lucknow, Uttar Pradesh, India ${ }^{2}$ Department of Obstetrics and Gynecology, M.L.N. Medical College, Allahabad, Uttar Pradesh, India

${ }^{3}$ Department of Obstetrics and Gynecology, IMS-BHU, Varanasi, Uttar Pradesh, India
\end{abstract}

Received: 08 May 2017

Accepted: 03 June 2017

\section{*Correspondence:}

Dr. Vandana Solanki,

E-mail: solanki.vandana@gamil.com

Copyright: ( ) the author(s), publisher and licensee Medip Academy. This is an open-access article distributed under the terms of the Creative Commons Attribution Non-Commercial License, which permits unrestricted non-commercial use, distribution, and reproduction in any medium, provided the original work is properly cited.

\begin{abstract}
Background: Polycystic ovarian syndrome is the most common hormonal disturbance in the reproductive age women, with prevalence of $5-10 \%$. Vitamin D deficiency is common in women with or without PCOS. The aim of this study was to assess association of serum vitamin D level with metabolic and endocrine dysregulation in women with PCOS.

Methods: This cross-sectional study was done over a period of one year. 100 women of age group 20-40 years were divided in group A $30\left(\right.$ BMI $\left.>30 \mathrm{mg} / \mathrm{m}^{2}\right)$ with PCOS, group B $20\left(\right.$ BMI $\left.<25 \mathrm{mg} / \mathrm{m}^{2}\right)$ with PCOS, group C 50 controls and were investigated for serum $\mathrm{FSH}, \mathrm{LH}, \mathrm{LH} / \mathrm{FSH}$ ratio, S. total testosterone, S. postprandial insulin level, glucose insulin ratio, 25 hydroxy vitamin $\mathrm{D}$ level.

Results: LH/FSH ratio $>2$ (33.33\% in obese and 50\% in non-obese), serum total testosterone level $>0.8 \mathrm{ng} / \mathrm{ml}(80 \% \mathrm{in}$ obese and $75 \%$ in non-obese) (p value was significant between study group as well as between study and control group). Serum fasting, postprandial blood glucose, postprandial serum insulin level was elevated in obese than nonobese PCOS. $25(\mathrm{OH})$ vitamin D deficiency $<20 \mathrm{ng} / \mathrm{ml}$ (56.675\% in obese and $45 \%$ in non-obese). So, vitamin D deficiency was more common in obese PCOS.

Conclusions: PCOS is more common in age group of 20-40 years. There is more Insulin resistance in obese PCOS as compared to non-obese PCOS. Vitamin D deficiency is comparatively more common in obese PCOS population than in non-obese PCOS.
\end{abstract}

Keywords: Non-obese PCOS, Obese PCOS, Vitamin D

\section{INTRODUCTION}

Polycystic ovarian syndrome is the most common hormonal disturbance in the reproductive age women, with prevalence of $5-10 \%$. It is characterized by the presence of polycystic ovaries, menstrual dysfunction, infertility and hyperandrogenimia. Long term complications are insulin resistance, impaired glucose tolerance, type-2 diabetes mellitus, dyslipidemia, cardiovascular disease and carcinomas including endometrial, breast and ovarian. ${ }^{1,2}$

The mechanism by which obesity influences the pathophysiology and clinical manifestation of PCOS are not completely understood, but obesity has an important impact on the severity of hyperandrogenism, menstrual irregularity and insulin resistance. ${ }^{3}$ Insulin resistance occurs in $50-70 \%$ of obese PCOS population and it has 20-30\% incidence in lean patients with PCOS. ${ }^{4}$ Insulin 
resistance and hyperinsulinimia is present in peripheral as well as ovarian compartment leading to hyperandrogenimia peripherally as well as in the ovaries thus affecting ovulation and causing hyperandrogenic features. ${ }^{5}$

Vitamin D is a lipid soluble steroid molecule, mainly produced by skin with a small amount absorbed in the gut from dietary sources. Though its main role is in the calcium and phosphorus homeostasis and bone metabolism, it regulates the expression of large number of gene in our body. Vitamin D enhances insulin action by enhancing insulin synthesis and/or suppression of proinflammatory cytokines that are believed to mediate insulin resistance. ${ }^{6}$

Vitamin D regulates estrogen biosynthesis by directly affecting the aromatase gene and by regulating extracellular calcium homeostasis. The most beneficial serum concentrations of $25(\mathrm{OH})$ are observed at level $>30 \mathrm{ng} / \mathrm{ml}(>75 \mathrm{nmol} / \mathrm{L})$. Most expert agree that vitamin D deficiency is present with $25(\mathrm{OH})$ vitamin levels of 21 $29 \mathrm{ng} / \mathrm{ml}$ and deficiency levels $<20 \mathrm{ng} / \mathrm{ml}$ (Chiu et al). ${ }^{7}$ Vitamin D deficiency leads to decreased aromatase activity in the ovary causing decreased production of progesterone and estradiol by pre ovulatory follicles, and increased level of $\mathrm{LH}$, thus altered folliculogenesis and ovulation. Currently vitamin D deficiency has also been implicated as a cause of insulin resistance and the development of PCOS.

\section{METHODS}

The present observational study was conducted over a period of 1 year. A total of 100 females in the age group of 20-40 years of age attending the outpatient department in Swaroop Rani Hospital and Kamla Nehru Memorial Hospital were enrolled in the study, after approval from ethical committee and obtaining an informed consent from the patient. The cases were divided into 3 groups, group A, group B, group C.

\section{Group A: 30 obese PCOS patients (BMI $>30 \mathrm{Kg} / \mathrm{m}^{2}$ )}

Group B: 20 non- obese PCOS patients $\left(\mathrm{BMI}<25 \mathrm{Kg} / \mathrm{m}^{2}\right.$ )

Group C: Age matched 50 normal females with normal menstruation and no hyperandrogenic features were taken.

All the patients included in the study were interviewed regarding age, parity, occupation, socioeconomic status. A detail history of symptoms of PCOS, like menstrual irregularity (oligomenorrhoea, secondary amenorrhoea), galactorrhoea, excessive facial hair, acne and hoarsening of voice were also taken. A thorough clinical examination including built height, weight, body mass index, waist/hip ratio, feature of hirsuitism, thyroid gland enlargement, acanthosis nigricans, breast examination for galactorrhoea was done. In married women per speculum examination and bimanual examination were done.

Afterwards blood investigations (complete blood count, liver function test, renal function test and fasting and postprandial blood sugar, 2 hour after 75 gram oral glucose), estimation serum FSH, LH hormone, LH/FSH ratio, serum prolactin level, serum total testosterone level, serum T3, T4, TSH level, serum insulin level, serum glucose level, glucose/insulin ratio and serum 25 hydroxy vitamin D level on D2 of menstrual cycle in fasting state between 8.00 AM-10.00AM, were sent. Finally, ultrasonographic examination (TAS and TVS) was done preferably on D2 or D3 of menses to scan ovaries.

\section{Inclusion criteria}

ESHRE/ASRM criteria for diagnosing PCOS.

\section{Exclusion criteria}

Other causes of hyperandrogenism, patient who have received any medication known to affect carbohydrate metabolism were excluded from study.

\section{Statistical analysis}

The results of continuous variables were expressed as mean \pm SD and proportions as percentages. The difference between the values and outcome were assessed by chi square and student test. For the entire test a $\mathrm{p}$ value of 0.05 or less was taken for statistical significance.

\section{RESULTS}

In present study $5(25 \%)$ in group B and $35(70 \%)$ subjects in control group $\mathrm{C}$ had BMI $<20 \mathrm{Kg} / \mathrm{m}^{2}, 15$ $(75 \%)$ in group B and $10(20 \%)$ in group C had BMI 21$25 \mathrm{~kg} / \mathrm{m}^{2}$. In group A $20(66.67 \%)$ had BMI $31-35 \mathrm{~kg} / \mathrm{m}^{2}$ and $10(33.33 \%)$ subjects had BMI $36-40 \mathrm{~kg} / \mathrm{m}^{2}$. The total no of patients in study group $(\mathrm{A}+\mathrm{B})$ had $\mathrm{BMI}<25 \mathrm{~kg} / \mathrm{m}^{2}$ were $20(40 \%)$, with BMI $31-35 \mathrm{~kg} / \mathrm{m}^{2}$ were $20(40 \%)$, with BMI $36-40 \mathrm{~kg} / \mathrm{m}^{2}$ were $10(20 \%)$. p value between study $(\mathrm{A}+\mathrm{B})$ and control was $<0.04$ which is statistically significant (Table 1).

In this study, $20(66.67 \%)$ cases of group A had serum LH level $<10 \mathrm{mIU} / \mathrm{ml}, 12(60 \%)$ cases of group B had serum $\mathrm{LH}<10 \mathrm{mIU} / \mathrm{ml}$ and in group $\mathrm{C}$ all cases had serum $\mathrm{LH}<10 \mathrm{mIU} / \mathrm{ml}$. Out of 30 cases in group A 10 $(33.33 \%)$ had serum LH level $>10 \mathrm{mIU} / \mathrm{ml}$ and out of 20 cases in group B $8(40 \%)$ had serum $\mathrm{LH}>10 \mathrm{mIU} / \mathrm{ml}$.

The total cases in the study group $(A+B) 32(64 \%)$ had serum $\mathrm{LH}$ level $<10 \mathrm{mIU} / \mathrm{ml}$ and $18(36 \%)$ had serum $\mathrm{LH}>10 \mathrm{mIU} / \mathrm{ml}$. The mean value of group A was $9.78 \pm 3.28$, in group B $10.57 \pm 4.06$, study group $\mathrm{A}+\mathrm{B}$ was $10.175 \pm 3.67$ and in control group $C$ mean value was $8 \pm 1.4$. $\mathrm{P}$ value of group $\mathrm{A}$ and $\mathrm{B}<0.05$ and study and control was 0.0001 . 
Table 1: Distribution of cases according to BMI.

\begin{tabular}{|lllllllll|}
\hline BMI $\left(\mathrm{kg} / \mathrm{m}^{2}\right)$ & Group A & & Group B & Study group $(\mathbf{A}+\mathbf{B})$ & Group C & No. \\
\hline & No. & \% & No. & \% & No. & \% & No. \\
\hline 20 & 0 & 0 & 5 & 25 & 5 & 10 & 35 & 70 \\
\hline $21-25$ & 0 & 0 & 15 & 75 & 15 & 30 & 10 & 20 \\
\hline $31-30$ & 0 & 0 & 0 & 0 & 0 & 0 & 0 & 0 \\
\hline $36-40$ & 20 & 66.67 & 0 & 0 & 20 & 40 & 5 & 10 \\
\hline Total & 10 & 33.33 & 0 & 0 & 10 & 20 & 0 & 0 \\
\hline Mean \pm SD & 30 & & 20 & & 50 & & 50 & \\
\hline
\end{tabular}

Table 2. Distribution of cases according to serum LH levels.

\begin{tabular}{|lllllllll|}
\hline Serum LH Level & \multicolumn{2}{c}{ Group A } & \multicolumn{2}{c}{ Group B } & \multicolumn{2}{c}{ Study Group } & \multicolumn{2}{c|}{ Group C } \\
& No. & \% & No. & \% & No. & \% & No. & \% \\
\hline$<10 \mathrm{mIU} / \mathrm{ml}$ & 20 & 66.67 & 12 & 60 & 32 & 64 & 50 & 100 \\
\hline$>10 \mathrm{mIU} / \mathrm{ml}$ & 10 & 33.33 & 8 & 40 & 18 & 36 & 0 & 0 \\
\hline Total & 30 & & 20 & & 50 & & 50 & \\
\hline Mean \pm SD & $9.78 \pm 3.28$ & & $10.57 \pm 4.06$ & & $10.175 \pm 3.67$ & $8 \pm 1.4$ \\
\hline
\end{tabular}

$\mathrm{P}$ value between group A and $\mathrm{B}<0.05, \mathrm{p}$ value between study and control $<0.0001$

Table 3. Distribution of cases according to serum LH/FSH ratio.

\begin{tabular}{|c|c|c|c|c|c|c|c|c|}
\hline \multirow[t]{2}{*}{$\begin{array}{l}\text { LH/FSH ratio } \\
(\mathbf{A}+\mathbf{B})(\text { Normal }<2)\end{array}$} & \multicolumn{2}{|c|}{ Group A } & \multicolumn{2}{|c|}{ Group B } & \multicolumn{2}{|c|}{ Study group } & \multicolumn{2}{|c|}{ Group C } \\
\hline & No & $\%$ & No. & $\%$ & No. & $\%$ & No. & $\%$ \\
\hline$<2$ & 20 & 66.67 & 10 & 50 & 30 & 60 & 50 & 100 \\
\hline$>2$ & 10 & 33.33 & 10 & 50 & 20 & 40 & 0 & 0 \\
\hline Total & 30 & & 20 & & 50 & & 50 & \\
\hline Mean \pm SD & 1.22 & & 2.77 & & $1.99=$ & & $1.2 \pm$ & \\
\hline
\end{tabular}

$\mathrm{P}$ value of group $\mathrm{A}$ and $\mathrm{B}=0.004, \quad \mathrm{p}$ value of study and control $<0.0001$

The difference between study and control group as well as between study groups $\mathrm{A}+\mathrm{B}$ was found to be significant (Table 2).

Out of 30 cases in group A $10(33.33 \%)$ had serum $\mathrm{LH} / \mathrm{FSH}$ ratio> 2. Whereas in group B, $10(50 \%)$ had ratio >2. $30(60 \%)$ in study group $(\mathrm{A}+\mathrm{B})$ had LH/FSH ratio $<2$ and $20(40 \%)$ had $\mathrm{LH} / \mathrm{FSH}$ ratio $>2$. $\mathrm{p}$ value of group A and B is 0.004 and $p$ value of study and control was 0.0001 . The difference between study and control group as well as between study groups (A and B) was found to be statistically significant (Table 3 ).

Table 4: Distribution of cases according to serum prolactin level.

\begin{tabular}{|lllllllll|}
\hline Serum prolactin & Group A & \multicolumn{3}{c}{ Group B } & \multicolumn{3}{c|}{ Group A+B (study group) } & Group C \\
\hline $5-25$ ng/ml & No. & \% & No. & \% & No. & \% & No. & \% \\
\hline $5-25$ & 6 & 20 & 6 & 30 & 12 & 24 & 49 & 98 \\
\hline $26-50$ & 24 & 80 & 14 & 70 & 38 & 76 & 1 & 2 \\
\hline Total & 30 & & 20 & & 50 & & 50 & $5 \pm 4.46$ \\
\hline Mean \pm SD & $31.6 \pm 9.6$ & & $25.77 \pm 11.55$ & $28.68 \pm 10.57$ & & 5 \\
\hline
\end{tabular}

In our study $24(80 \%)$ in group A and $14(70 \%)$ cases in group $\mathrm{B}$ and only $1(2 \%)$ in group $\mathrm{C}$ had serum prolactin level in range of $26-50 \mathrm{ng} / \mathrm{ml}$. Where as in the study group $(\mathrm{A}+\mathrm{B}) 38(76 \%)$ had serum prolactin level in the range of $26-50 \mathrm{ng} / \mathrm{ml}$.
The difference between study and control group was extremely significant, but between study group A and B it was not significant (Table 4). Out of 30 cases in group A $24(80 \%)$ and out of 20 cases $17(75 \%)$ in group B had serum total testosterone level $>0.8 \mathrm{ng} / \mathrm{dl}$. 
Table 5: Distribution of cases according to serum total testosterone levels.

\begin{tabular}{|c|c|c|c|c|c|c|c|c|}
\hline \multirow[t]{2}{*}{$\begin{array}{l}\text { Serum total } \\
\text { testosterone level } \\
(0.2-0.8 \mathrm{ng} / \mathrm{dl})\end{array}$} & \multicolumn{2}{|c|}{ Group A } & \multicolumn{2}{|c|}{ Group B } & \multicolumn{2}{|c|}{$\begin{array}{l}\text { Group A+B } \\
\text { (study group) }\end{array}$} & \multicolumn{2}{|c|}{ Group C } \\
\hline & No. & $\%$ & No. & $\%$ & No. & $\%$ & No. & $\%$ \\
\hline $0.2-0.8 \mathrm{ng} / \mathrm{dl}$ & 6 & 20 & 3 & 15 & 9 & 18 & 50 & 100 \\
\hline$>0.8 \mathrm{ng} / \mathrm{dl})$ & 24 & 80 & 17 & 75 & 41 & 82 & 0 & 0 \\
\hline Total & \multicolumn{2}{|l|}{30} & \multicolumn{2}{|l|}{20} & \multicolumn{2}{|l|}{50} & \multicolumn{2}{|l|}{50} \\
\hline Mean \pm SD & \multicolumn{2}{|c|}{$2.38 \pm 1.49$} & \multicolumn{2}{|c|}{$1.15 \pm 0.047$} & \multicolumn{2}{|c|}{$1.76 \pm 0.765$} & \multicolumn{2}{|c|}{$0.2 \pm 0.15$} \\
\hline
\end{tabular}

$\mathrm{P}$ value of group $\mathrm{A}$ and $\mathrm{B}=0.0008 \mathrm{P}$ value of study and control 0.0001

Table 6: Distribution of cases according serum 25- hydroxy vitamin D levels.

\begin{tabular}{|lllllllll|}
\hline Serum total vit D2 level & Group A & \multicolumn{3}{l}{ Group B } & Group A+B (study group) & Group C \\
& No. & \% & No. & \% & No. & \% & No. & \% \\
\hline $3-100$ & 6 & 20 & 7 & 35 & 13 & 26 & 40 & 80 \\
\hline $20-29$ & 7 & 23.33 & 4 & 20 & 11 & 22 & 10 & 20 \\
\hline$<20$ & 17 & 56.67 & 9 & 45 & 26 & 52 & 0 & 0 \\
\hline Total & 30 & & 20 & & 50 & & 50 & \\
\hline Mean \pm SD & $18.14 \pm 14.53$ & $19.96 \pm 14.56$ & $19 \pm 14.5$ & & $61.62 \pm 25.63$ \\
\hline
\end{tabular}

$\mathrm{P}$ value of group $\mathrm{A}$ and $\mathrm{B}<0.05$ and $\mathrm{p}$ value of study and control $<0.0001$

Table 7: Comparisons of $25(\mathrm{OH})$ vitamin $\mathrm{D}$ deficiencies with insulin resistance and glucose intolerance.

\begin{tabular}{|lllllll|}
\hline & \multicolumn{2}{c}{ Group A (Obese) } & \multicolumn{2}{c|}{ Group B (Non obese) } & \multicolumn{2}{c|}{ Study group (A+B) Aggregate } \\
\hline & No. & $\mathbf{\%}$ & No. & \% & No. & $\%$ \\
\hline Postprandial insulin level & 15 & 50 & 9 & 45 & 24 & 48 \\
\hline Fasting glucose/insulin ratio & 20 & 66.67 & 8 & 28 & 28 & 56 \\
\hline Vitamin D deficiency & 17 & 56.67 & 9 & 45 & 26 & 52 \\
\hline
\end{tabular}

The mean value of serum total testosterone in group $\mathrm{A}$ was $2.38 \pm 1.49$, in group B was $1.15 \pm 0.47$, study group $\mathrm{A}+\mathrm{B}$ was $1.76 \pm 0.765$ and in control group $\mathrm{C}$ the mean value was $0.2 \pm 0.15$. $p$ value of group and $B$ was.0008 and $\mathrm{p}$ value of study and control was 0.0001 . The difference between study and control as well as between study group was found to be statistically significant (Table 5). 7 $(23.33 \%)$ cases in group A, $4(20 \%)$ cases in group B and $10(20 \%)$ in group C had vitamin D insufficiency (20-29 $\mathrm{ng} / \mathrm{ml})$. Maximum cases in group A 17 (56.67\%) and 9 $(45 \%)$ in group $B$ had serum hydroxy vitamin D deficiency. The mean value of serum hydroxy vitamin $\mathrm{D}$ in group A was $18.14 \pm 14.53$, in group B was $19.965 \pm 14.56$, group $A+B$ was $19 \pm 14.5$ and in control group $C$ the mean value was $70 \pm 0.532$. $P$ value of group $\mathrm{A}$ and $\mathrm{B}$ was $<0.05$ and study and control it was $<0.0001$.

The statistical difference between study group $(\mathrm{A}+\mathrm{B})$ was found to be insignificant but between study and control it is significant (Table 6).

In group A, $15(50 \%)$ cases, 9 (45\%) cases of group B had insulin resistance. In group A $20(66.67 \%)$ cases and $8(40 \%)$ cases of group B had fasting glucose/ insulin ratio $<4.5 \% .17(56.67 \%)$ cases of group A and $9(45 \%)$ cases of group B had vitamin D deficiency (Table 7).

\section{DISCUSSION}

Maximum number of patients in group A $(66.67 \%)$ had $\mathrm{BMI}$ in the range of $31-35 \mathrm{~kg} / \mathrm{m}^{2}$. In non-obese PCOS maximum number of patients $(75 \%)$ had $\mathrm{BMI}$ in the range of $21-25 \mathrm{~kg} / \mathrm{m}^{2}$. On taking all the PCOS patients, $60 \%$ had BMI $31-40 \mathrm{~kg} / \mathrm{m}^{2}$, indicating that PCOS population is more prone to obese or overweight whereas in control group maximum patients $(70 \%)$ had BMI $<20$ $\mathrm{kg} / \mathrm{m}^{2}$ with a statistical significant variation of BMI between study and control group ( $\mathrm{p}$ value<0.04).

In present study maximum $8(40 \%)$ of group B (nonobese PCOS) cases had LH value $>10 \mathrm{mIU} / \mathrm{ml}$ than 10 $(33.33 \%)$ group A (obese PCOS). The result of our study was comparable to study done by Balen et al and Baldani et al. ${ }^{8}$ Balen et al studied 1741 PCOS women, diagnosed by ultrasound, $\mathrm{LH}>10 \mathrm{mIU} / \mathrm{ml}$ was found to be raised in $44 \%$. The mean value of serum LH in obese PCOS is $6.3 \pm 2.2$ and non-obese $9.9 \pm 4.7$ and $p$ value was .001 , which was significant. In non-obese PCOS the serum LH level is more elevated than obese PCOS. As LH is high it contributes to high concentration of androgen in nonobese PCOS while in obese PCOS raised insulin is responsible for the same. The mean value of serum prolactin in obese was 31.6 \pm 9.6 , in group B was 
$25.77 \pm 11.55$, study group $\mathrm{A}+\mathrm{B}$ was $28.68 \pm 10.57$ and in control group $\mathrm{C}$ it was $5 \pm 4.46$. p value between study group was .0584 which is insignificant but between study and control it was highly significant $(<0.0001)$. The result of present study was comparable with Najem F et al and Mahmood MI. ${ }^{9,10}$

Najem $\mathrm{F}$ et al did a retrospective analysis of patient records at the endocrine clinic in Benghazi on 318 PCOS women. In their study serum prolactin was raised in $31 \%$ in obese PCOS population and according to Manal et al the mean value of serum prolactin in obese PCOS was $24.9 \pm 2.37$ and in non-obese were $21.6 \pm 5.65$, $\mathrm{p}$ value was .069. They found that of serum prolactin in obese PCOS was more as compared to non-obese PCOS. The possible cause of raised prolactin may be increased adrenal gland androgen production. This high prolactin level may further aggravate oligomenorrhoea and amenorrohea. Prolactin also has antigonadotropic activity thus lowers serum FSH levels.

In present study, total testosterone level was higher in obese PCOS than non-obese PCOS. Mean value in group A was $2.38 \pm 1.49$, in group B was $1.15 \pm 0.47$, study group $(\mathrm{A}+\mathrm{B})$ was $1.76 \pm 0.765$ and in control group $\mathrm{C}$ it was $0.2 \pm 0.15$. Present study results were comparable to Mahmood MI et al. ${ }^{10}$ In their study serum total testosterone was raised in obese PCOS population ( $p$ value $=0.009$ ). This is due to obesity itself that cause hyperandrogenic state due to decreased sex hormone binding protein and increased serum free testosterone.

$\mathrm{P}$ value of Serum 25 hydroxy D2 level between group A and B was .05 and between study and control $<0.0001$. The statistical difference between both study groups (A, B) was found to be insignificant but difference between study and control group was found to be significant. Results of our study were comparable with Yildizhan R et al and Wehr E et al. ${ }^{11,12}$ They studied on 100 PCOS women and divided into two obese and non-obese PCOS according to their body mass index, and concluded that serum 25- hydroxy vitamin D2 $56.31 \%$ lower in obese PCOS patients.

Wehr E et al studied on 250 women with PCOS. In PCOS who had more BMI the vitamin D2 level lower than normal BMI PCOS. ${ }^{12} \mathrm{He}$ concluded that there is inverse correlation between BMI and 25 hydroxy levels in PCOS. 25 hydroxy vitamin D is positively correlated with insulin sensitivity and negatively with beta cell function. Vitamin $\mathrm{D}$ is thought to play a role in pathogenesis type II diabetes by affecting insulin metabolism. Vitamin D enhances insulin action by enhancing insulin synthesis and insulin release. Vitamin D receptors have also been demonstrated to be present in ovary and endometrium exerting its effect through gene transcription and hormonal modulation, vitamin $\mathrm{D}$ regulates estrogen biosynthesis by directly affecting the aromatase gene and by regulating extracellular calcium homeostasis. Vitamin $\mathrm{D}$ deficiency leads to decreased aromatase activity in the ovary causing decreased production of progesterone and estradiol by preovulatory follicles, and increased level of $\mathrm{LH}$, thus altered folliculogenesis and ovulation.

So, it is evident now that vitamin D deficiency is more common in PCOS than general women, hence administrating vitamin $\mathrm{D}$ formulation to these women may help in reducing symptomatology in PCOS and risk of long term complications like diabetes mellitus, cardiovascular disease.

Funding: No funding sources

Conflict of interest: None declared

Ethical approval: The study was approved by the Institutional Ethics Committee

\section{REFERENCES}

1. Cussons AJ, Watts GF, Burke V, Shaw JE, Zimmet PZ, Stuckey BG. Cardio metabolic risk in polycystic ovarian syndrome a comparison of different approaches to defining the metabolic syndrome. Hum Reprod. 2008;23:2532-8.

2. Barber TM, Frank S. The link between polycystic ovarian syndrome and both type 1 and 2 diabetes mellitus. What we know today? Women's health. 2012;8(2):147-54.

3. Pasquali R, Gambineri A, Pagotto U. The impact of obesity on reproduction in women with polycystic ovary syndrome. BJOG .2006;113:1148-59.

4. Hahn S, Haselhorst U, Tan S, Quadbeck B, Schmidt M, Roesler S et al. Low serum 25-hydroxy vitamin D concentrations are associated with insulin resistance and obesity in women with polycystic ovarian syndrome. Exp Clin Endocriol Diabetes. 2006;114(10):577-83.

5. Barberi RL, Makris A, Randall RW, Daniels G, Kistrer RW, Ryan KJ. Insulin stimulates androgen accumulation in ovarian stroma obtained from women with hyperandrogenism. J Endocrinal Metab. 1986;62(5):904-10

6. Teegarden D, Donkin SS. Vitamin D: emerging new roles in insulin sensitivity. Nutr Res Rev. 2009;22:82-92.

7. Chiu KC, Chu A, Go VL, Saad MF. Hypovitaminosis D is associated with insulin resistance and beta cell dysfunction. AM J Clin Nutr. 2004;79(5):820-5.

8. Balen AH, Conway GS, Kaltsas G, Techatraisak K, Manning PJ, West $\mathrm{C}$ et al. Polycystic ovarian syndrome: The spectrum of the disorder in 1741 patients. Human Reprod. 1995;10:2107-11.

9. Najem FI, Eehdawi, Swalem AM. Clinical and biochemical characteristic of polycystic ovary syndrome in Benghazi - Libya; A Retrospective study. Libyan J Med. 2008;3(2):71-74.

10. Mahmood MI, Habeeb F, Kasim K. Reproductive and biochemical change in obese non-obese polycystic ovary syndrome women. Alaxandria J Med. 2015;51(1):5-9. 
11. Yildizhan R, Kurdoglu M, Adali E, Kolusari A, Yildizhan B. Serum 25 hydroxy vitamin D concentration in obese and non-obese women with polycystic ovary syndrome. Arch Gynecol Obstet. 2009;280(4):559.

12. Wehr E, Pilz S, Schweighofer N, Giuliani A, Kopera D, Pieber, Obermayer-Pietsch B. Association of hypovitaminosis $\mathrm{D}$ with metabolic disturbances in polycystic ovarian syndrome. Eur J Endocrinol. 2009;161(4):575-82.

Cite this article as: Solanki V, Chaurasia A, Singh S, Sachan S, Varma K, Devi R. Estimation of serum 25 hydroxy vitamin $\mathrm{D}$ level and its correlation with metabolic and endocrine dysregulation in women with PCOS. Int J Reprod Contracept Obstet Gynecol 2017;6:3085-90. 